GAO Report to Congressional Requesters

September 2003

\title{
CHARTER SCHOOLS
}

New Charter Schools

across the Country

and in the District of

Columbia Face Similar

Start-Up Challenges

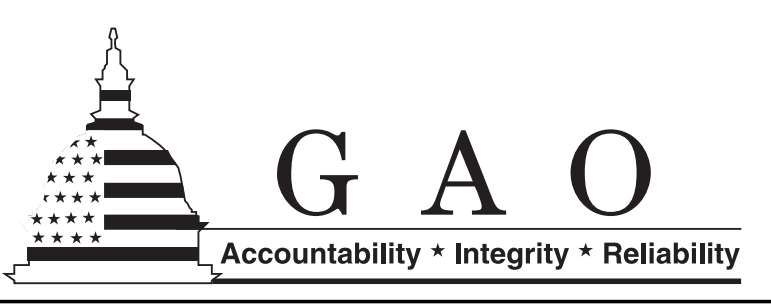




\section{G A O Accountability $\cdot$ Integrity $\cdot$ Reliability Highlights}

Highlights of GAO-03-899, a report to congressional requesters

\section{New Charter Schools across the Country and in the District of Columbia Face Similar Start-Up Challenges}

\section{Why GAO Did This Study}

As of the 2002-2003 school year, nearly 2,700 charter schools operated in 36 states, the District of Columbia, and Puerto Rico. Charter schools are public schools that are exempt from certain state and local regulations in exchange for agreeing to certain student performance goals.

To increase their understanding of problems faced during the start-up process, Congress included a provision in the Omnibus Appropriations Bill for Fiscal Year 2003 (P.L. 108-7), which required GAO to report on charter school start-ups, including a comparison with charter schools in the District of Columbia. This report examines (1) the challenges faced by charter school start-ups across the nation and the resources available in various states to address these challenges and (2) how the District of Columbia compares in terms of charter school challenges and resources. To address these objectives, GAO analyzed federal, state, and D.C. charter school laws and interviewed Education and District officials, including representatives of the D.C. charter school authorizing boards, the D.C. public school system, and various city offices. GAO also conducted a discussion group consisting of District charter school experts and D.C. charter school founders.

\section{What GAO Found}

Securing a facility, obtaining start-up funding, and, to a lesser extent, acquiring the expertise necessary to run a charter school are the three greatest challenges facing new charter school founders nationwide, although the extent of the challenges varied from state to state. Charter school advocates report that charter schools need buildings that allow them to grow as their enrollment grows and that they have limited access to financing for facilities - both of which make securing facilities one of the most difficult aspects of opening a new charter school. Additionally, charter schools report that obtaining start-up money, particularly early in the charter application and planning periods, is difficult. In gaining approval for charters, they may incur significant expenses, such as hiring experts to review charters, purchasing curriculum programs, and placing down payments on facilities, before becoming eligible to receive most forms of public funding. Another challenge facing new charter school founders is acquiring the expertise-business, legal, managerial-necessary to open and run a charter school.

Several federal, state, and local programs are available to help charter schools address these challenges across the country and in the District of Columbia. At the federal level, the Public Charter Schools Program has awarded about $\$ 1$ billion in grants since 1994 to charter schools to help offset their start up costs. The program has also provided additional funding for a limited number of grants to organizations to increase charter schools' access to facilities financing. Some states also provide assistance to charter schools to address these challenges as shown in the following table.

\begin{tabular}{lr} 
Type of assistance & Number of states \\
\hline Funding assistance for facilities & 11 and D.C. \\
\hline Access to vacant public buildings & 18 and D.C. \\
\hline Provide start-up grants or low or no interest loans & 9 and D.C. \\
\hline Technical assistance programs & 28 and Puerto Rico \\
\hline
\end{tabular}

Source: GAO analysis of state charter school laws and Education Commission of the States.

The challenges facing D.C. charter schools are similar to those around the country; however, obtaining facilities is particularly difficult in D.C. due to the cost of real estate and poor condition of available buildings. To offset this challenge, the District provides charter schools with various forms of assistance, including a limited preference to buy or lease surplus public school buildings and a per-pupil allotment for the cost of facilities. To address challenges associated with start-up funding, the District provides charter schools with some funding prior to schools' opening. Although the District chartering authorities provide some guidance to charter applicants, they do not provide them with general technical assistance. 


\section{Contents}

\section{Letter}

Results in Brief

Background

Facilities, Funding, and, to a Lesser Extent, Expertise Pose

Challenges for New Charter Schools, but Some Assistance Is

Available

District of Columbia Charter Schools Face Similar Challenges, but

More Facilities Assistance Is Available

Concluding Observations

Appendix I

Scope and Methodology

Appendix II

Charter School Facility Assistance Provisions, as of July 2003

Appendix III

Charter Schools Operating during 2002-03 School

Year in D.C. and Facility Status

Appendix IV

A Comparison of Number of Charter Schools and Select Resources Available

Appendix V

GAO Contacts and Staff Acknowledgments

GAO Contacts

37

Staff Acknowledgments

\section{Tables}




\section{Figures}

Figure 1: Status of Charter School Laws by Jurisdiction as of July 2003

Figure 2: Expertise Needed to Open a Charter School

Figure 3: Kinds of Facilities Assistance Provided through the District to Charter Schools Operating during School Year 2002-2003

Figure 4: Timeline of D.C. Public Chartering Process and Eligibility for Public Funds

\begin{tabular}{ll}
\hline Abbreviations \\
DCPS & District of Columbia Public Schools \\
CSDC & Charter Schools Development Corporation \\
PCS & Public Charter School \\
QZAB & Qualified Zone Academy Bond
\end{tabular}

This is a work of the U.S. government and is not subject to copyright protection in the United States. It may be reproduced and distributed in its entirety without further permission from GAO. However, because this work may contain copyrighted images or other material, permission from the copyright holder may be necessary if you wish to reproduce this material separately. 
September 3, 2003

The Honorable Mike DeWine

Chairman

The Honorable Mary Landrieu

Ranking Minority Member

Subcommittee on the District of Columbia

Committee on Appropriations

United States Senate

The Honorable Rodney P. Frelinghuysen

Chairman

The Honorable Chaka Fattah

Ranking Minority Member

Subcommittee on the District of Columbia

Committee on Appropriations

House of Representatives

The growing popularity of educational choice was highlighted in a May 2003 study by the Department of Education's National Center for

Education Statistics that reported a shift in public school enrollment away from public, assigned schools into public, chosen schools from 1993-1999. Charter schools are one of the primary ways that parents can exercise choice in the public school system. While their impact on student achievement is still being debated, charter schools are a form of educational reform that has enjoyed bipartisan support from Congress and other policy makers. Since 1994, the federal government has provided about $\$ 1$ billion in grants to charter schools in addition to financial support provided by state and local governments.

Currently about 1.5 percent of students nationwide, and 15 percent in the District of Columbia, are attending charter schools. Charter schools are public schools that are exempt from certain state and local regulations in exchange for accountability for improving student achievement. Like traditional public schools, charter schools receive funding from state and local governments on a per-pupil basis; however, unlike traditional public schools, charter schools are responsible for a wide range of functions that are usually administered by the local school district, such as managing faculty payroll and securing and maintaining school facilities. Other resources available to charter schools depend on specific state laws, local 
school district decisions, and the availability of private or nonprofit assistance.

The opening of a charter school can present challenges to the founders. While the challenges are similar, the extent of these challenges varies from state to state, depending on state laws and procedures and the resources available to assist in the start-up process. This report provides information on (1) challenges faced by charter school start-ups across the nation and resources available in various states to address these challenges and (2) how the District of Columbia compares in terms of challenges and resources. ${ }^{1}$

To obtain information about charter school start-ups across the country, we analyzed federal and state charter school laws. We conducted interviews with Department of Education (Education) officials, charter school policy experts, and charter school advocates in various states, including a charter school founder. We also reviewed a variety of national studies and surveys of charter schools, including those done by the Education Commission of the States and for the Department of Education. To obtain information about charter schools in the District of Columbia, we analyzed District of Columbia and federal laws affecting charter schools in the District. We interviewed officials from the Mayor's office and the City Council, the District of Columbia Public Schools, and both charter school authorizing bodies-the District of Columbia Public Charter School Board and the District of Columbia Board of Educationfrom whom we obtained much of our information about the facility status of currently operating charter schools. We conducted a discussion group consisting of District representatives from charter school advocacy groups, researchers, charter school founders, and other individuals knowledgeable of charter school issues in the District of Columbia. We also visited 1 of the 39 charter school campuses operating in the District in the 2002-2003 school year. See appendix I for a more complete description of our scope and methodology. We conducted our work between February and September 2003 in accordance with generally accepted government auditing standards.

${ }^{1}$ The Consolidated Appropriations Resolution for Fiscal Year 2003, Division C, Title III, $\S 140$, Pub. L. No. 108-7 (2003), required GAO to report on the national effort to establish adequate charter school facilities, including a comparison to the efforts in the District of Columbia. 

process, new charter schools across the country share common difficulties securing adequate facilities, obtaining start-up funding, and, to a lesser extent, acquiring the expertise necessary to run a charter school.

According to studies conducted for Education and national charter school experts, finding and financing adequate facilities is one of the two most challenging aspects of starting a new charter school. To address this problem, the federal Public Charter Schools Program provides a limited number of grants to improve the creditworthiness of charter schools and help offset the cost of acquiring, constructing, or renovating facilities. Additionally, 27 of the 40 states with charter school laws and the District of Columbia have provisions in law providing for facilities-related assistance to charter schools. The extent of this assistance varies considerably; however, ranging from allowing charter schools to use vacant public buildings if they are available to providing funding and lowinterest loans to cover some building expenses. A second major challenge cited by studies conducted for Education is obtaining sufficient start-up funding. New charter schools incur numerous expenses during the school design and planning phases, such as purchasing supplies and hiring faculty, before many are eligible to receive most forms of public funding. One federal resource available to mitigate this problem is the federal Public Charter Schools Program, which provides annual grants that can be used for charter school planning, design, and implementation.

Additionally, approximately one-quarter of states with charter school laws provide charter school start-up grants or low-interest loans. Finally, charter school advocates cite the wide range of expertise needed, including accounting, budgeting, education law, and general school management as a significant challenge to opening a new school. Few federal government resources exist to help charter school founders acquire issue area expertise; however, 28 states and Puerto Rico provide charter schools with some technical assistance according to the Education Commission of the States. Nonprofit resource centers and other nongovernment sources have been established in some states to provide new charter schools with various forms of technical assistance to help bridge knowledge gaps.

Charter school founders and others knowledgeable about charter schools in the District of Columbia report these same three challenges, and except for receiving greater assistance with funding facilities, have generally similar resources. Charter school founders in the District report difficulties locating appropriate buildings and paying for them, citing real estate costs and the age and poor condition of available buildings as contributing factors. However, in contrast to charter schools in most 
states, the D.C. law gives charter schools a limited preference to access surplus public school buildings and a facilities allowance. Like charter schools in other states, new charter school founders in the District reported a variety of expenses early in the design and planning stages and thus cited obtaining start-up funding as a significant challenge to starting a new charter school. To help with this problem, the District provides some early funding prior to schools' opening. However, to obtain this funding charter schools must meet eligibility requirements, such as acquiring a facility. Finally, new charter school founders in the District also reported that they need expertise in a wide range of areas to successfully open and operate a charter school. Similar to charter schools in other parts of the country, District charter school founders receive some advice and technical assistance during the chartering process; however, unlike charter schools in some other states, District charter schools have few readily available resources to address this challenge. According to some local charter school founders, the nonprofit D.C. Charter School Resource Center's recent closing has limited the amount of assistance available to help new charter schools founders acquire the necessary expertise.

Since the opening of the first public charter school in Minnesota in 1992, approximately 2,700 public charter schools have opened across the country. As shown in figure 1, 40 states, the District of Columbia, and Puerto Rico have enacted charter school laws, although, as of July 2003, no charter schools had opened in 4 of these states-Iowa, Maryland, New Hampshire, and Tennessee. In the 2002-2003 school year, public charter schools enrolled nearly 700,000 students or approximately 1.5 percent of America's 48 million public school students in prekindergarten through 12th grade. Students enrolled in charter schools are more likely to be members of minority groups than students enrolled in traditional public schools according to a 4-year study of charter schools conducted for Education. ${ }^{2}$

${ }^{2}$ RPP International, Office of Educational Research and Improvement, U.S. Department of Education, The State of Charter Schools 2000: Fourth Year Report (Washington, D.C.: Jan. 2000). 
Figure 1: Status of Charter School Laws by Jurisdiction as of July 2003
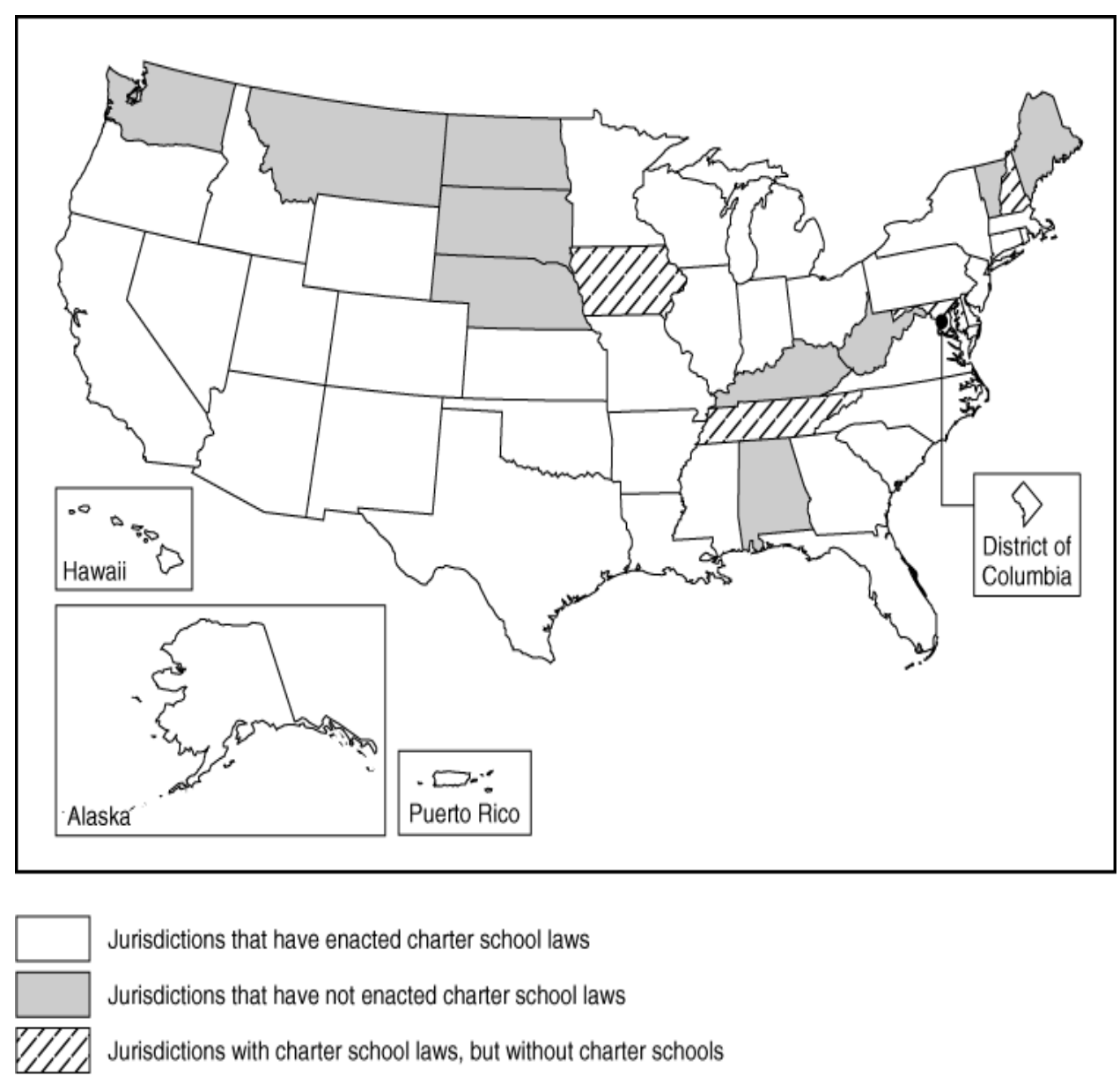

$$
\begin{aligned}
& \text { Jurisdictions that have enacted charter school laws } \\
& \text { Jurisdictions that have not enacted charter school laws } \\
& \text { Jurisdictions with charter school laws, but without charter schools }
\end{aligned}
$$

Source: GAO's analysis of state charter school legislation as of July 2003.

Charter schools are public schools established under contracts that grant them greater levels of autonomy from school regulations in exchange for agreeing to certain student performance goals. Charter schools are often exempt from certain state and school district education laws and in some states may receive waivers for exemptions from other laws; however, charter schools must comply with select regulations, including those pertaining to special education, civil rights, and health and safety conditions. While charter schools are free from many educational regulations, they are accountable for their educational and budgetary performance, including the assessment requirements of the No Child Left 
Behind Act. ${ }^{3}$ Charter schools may have their charters revoked by the authorizing body if they fail to perform adequately.

Charters to operate a school are awarded by various entities, depending on the state's laws, but may include local school districts, state education agencies, institutions of higher education, municipal governments, or special chartering boards. The majority of charter school authorizing bodies have formal procedures to regulate the charter application process, including formal application deadlines and public hearings. The ease of the authorizing process for charter schools varies from state to state, depending on the specifications in state law governing charters and local support or resistance to charter schools. For instance, some states limit the number of charters that may be awarded either in total or by year. Also, some state laws specify multiple authorizers, while others restrict approval authority to a single entity, for example, a local school board, and provide for appeal when a charter is denied.

In addition to awarding charters, authorizing bodies are responsible for monitoring school performance in areas such as student performance, compliance with regulations, financial record keeping, and special education services. If charter schools do not meet expected performance measures, authorizing bodies may revoke a school's charter or decide not to renew the school's charter when it expires. Since 1992, more than 100 charter schools have been closed, either through charter revocation or nonrenewal. According to a recent study published by the Thomas B. Fordham Institute, the majority of these closings have been due to financial mismanagement, while the rest have been closed due to unsatisfactory student achievement or other performance failures. ${ }^{4}$

A wide range of individuals or groups, including parents, educators, nonprofit organizations, and universities, may apply for a school charter as nonprofit organizations. Similar to other nonprofit organizations, charter schools are governed by a board of trustees, which is selected by the

\footnotetext{
${ }^{3}$ P. L. 107-110 (2002). The No Child Left Behind Act reauthorized the Elementary and Secondary Education Act of 1965 and instituted a number of new features that hold schools accountable for student achievement.

${ }^{4}$ Thomas B. Fordham Institute, Charter School Authorizing: Are States Making the Grade? (Washington, D.C.: June 2003). The Thomas B. Fordham Institute is a nonprofit organization associated with the Thomas B. Fordham Foundation, which supports research, publications, and action projects about elementary and secondary education reform.
} 
school founders. Although requirements for charter school board membership vary across states, charter school boards are responsible for school oversight. Specifically, charter school boards oversee legal compliance, contracts with external parties, financial management and policies, and facilities and equipment acquisition and maintenance. Charter school board members are also responsible for identifying real and potential risks facing the charter school, such as financial and school liability risks and emergency preparedness, and taking steps to reduce or eliminate these risks.

Charter schools may be established in one of two ways. First, an existing school may be converted to a public charter school. Traditional public schools may convert to charter schools to focus on a specific segment of the student body, such as at-risk students, to apply a new curriculum or educational approach, or to operate in a less regulatory environment. Charter schools may also be established when a new school is created and awarded a charter. The majority of charter schools are newly created schools rather than conversion schools. According to a study done for Education, in the 2000-2001 school year, 76 percent of new charter schools were newly created. ${ }^{5}$ Charter schools that are converted from existing schools generally remain in their buildings, while newly created charter schools must acquire facilities. These newly created charter schools may operate in a variety of facilities, including surplus school buildings, shared space with other groups, such as the YMCA or other charter schools, and converted commercial buildings, including office and retail space. In September 2000, we reported that new charter schools often experience difficulty financing the purchase or lease of their facilities. ${ }^{6}$

With approximately 15 percent of its public school students attending charter schools, the District of Columbia has one of the highest concentrations of public students in charter schools in the country. Like most charter schools, District charter schools have lower average total enrollments and student to teacher ratios than traditional public schools. Additionally, District charter schools, like their national counterparts, serve a higher percentage of minority and low-income students than

\footnotetext{
${ }^{5}$ SRI International, Policies and Program Studies Service, U.S. Department of Education, A Decade of Public Charter Schools, Evaluation of the Public Charter Schools Program: 2000-2001 Evaluation (Washington, D.C.: Nov. 2002).

${ }^{6}$ See U.S. General Accounting Office, Charter Schools: Limited Access to Facility Financing, GAO/HEHS-00-163 (Washington, D.C.: Sept. 12, 2000).
} 
traditional public schools. Charter school applicants in the District may apply to either of two authorizing entities, the District of Columbia Public Charter School Board or the District of Columbia Board of Education. As of the 2002-2003 school year, the D.C. Public Charter School Board has authorized charters for 23 schools, 1 of which closed voluntarily. The D.C. Board of Education has authorized charters for 21 schools, 6 of which closed for performance and management reasons. Three new charter schools, 1 authorized by the Board of Education and 2 by the D.C. Public Charter School Board, are expected to open in the 2003-2004 school year.

Table 1: D.C. Chartering Authorities

\begin{tabular}{|c|c|c|}
\hline D.C. chartering authorities & $\begin{array}{r}\text { D.C. Board of Education } \\
\text { Chartering Office }\end{array}$ & $\begin{array}{r}\text { D.C. Public Charter School } \\
\text { Board }\end{array}$ \\
\hline $\begin{array}{l}\text { Fiscal year } 2003 \text { chartering } \\
\text { authority budget }\end{array}$ & $\$ 300,000$ & $\$ 589,000$ \\
\hline $\begin{array}{l}\text { Number of chartering authority } \\
\text { board members }\end{array}$ & 9 & 5 \\
\hline $\begin{array}{l}\text { Number of charter schools } \\
\text { authorized }^{\mathrm{a}}\end{array}$ & 21 & 23 \\
\hline $\begin{array}{l}\text { Number of charter schools } \\
\text { closed }\end{array}$ & 6 & 1 \\
\hline $\begin{array}{l}\text { Number of charter schools } \\
\text { operating during the 2002- } \\
2003 \text { school year }\end{array}$ & 14 & $21^{b}$ \\
\hline $\begin{array}{l}\text { Number of new charter } \\
\text { schools expected to open in } \\
\text { the } 2003-2004 \text { school year }\end{array}$ & 1 & 2 \\
\hline $\begin{array}{l}\text { Number of enrolled students } \\
\text { as of } 2002-2003 \text { school year }\end{array}$ & 2,949 & 8,723 \\
\hline Average school size & 211 students & 411 students \\
\hline
\end{tabular}

Source: GAO's analysis of D.C. public school data.

${ }^{a}$ The number of charter schools authorized reflects the number of charters awarded. Each charter is awarded to one school that may operate on one campus or on a number of campuses. For example Friendship-Edison was awarded 1 charter, but operates 4 campuses, each with its own building.

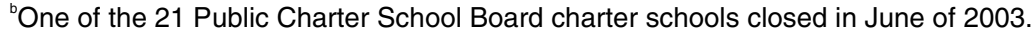


Facilities, Funding, and, to a Lesser Extent, Expertise Pose Challenges for New Charter Schools, but Some Assistance Is Available
New charter school founders across the country share common challenges: securing adequate facilities, obtaining start-up funding, and, to a lesser extent, acquiring the expertise necessary to run a charter school, although various forms of assistance are available to help with the start-up process. Securing adequate facilities is one of the greatest challenges facing new charter schools, according to research articles and national charter school experts. The federal government and 27 states provide limited assistance to address this problem. Charter schools also report facing difficulties obtaining funding during the application and early implementation periods, although the federal government and a small number of states provide funding for charter school start-up grants. The wide array of knowledge and skills necessary to open and operate a new charter school, such as business, law, management, and education expertise, also presents a challenge, according to charter school founders. Few federal programs exist that specifically address this challenge; however, some assistance is available from state, local, and nonprofit sources.

According to research articles and national charter school experts, securing adequate facilities is one of the most challenging aspects of starting a new charter school. Unlike traditional public schools that rely on school districts for support, charter schools are responsible for locating, securing, and renovating their school buildings. Locating an appropriate facility can be difficult for new charter schools. Because new charter schools often open with few classrooms or grades and a limited number of enrolled students, charter schools frequently expand significantly, sometimes by several grades, during their first few years of operation. As a result, new charter schools either look for a smaller building that will meet their current size needs or a larger one that will accommodate future growth. Both options can pose problems for new charter schools, as opening in a smaller building requires an ongoing search for a larger facility and the expense of a future move, while selecting a larger facility, if one can be found, may not be financially feasible in a school's early years. Additionally, schools have facilities requirements - they need facilities that will enable them to subdivide space into classrooms and also contain common space to serve as gymnasiums, cafeterias, or auditoriums. Transforming commercial space into educational facilities with classrooms and common rooms can be expensive. Some charter schools are able to acquire existing school buildings to use for facilities, which can reduce transformation costs; however, the number of excess school buildings available is generally limited. 
In addition to encountering difficulties locating appropriate facilities, charter schools have difficulty financing the building purchase or lease and renovations. Traditional public schools generally rely on school districts for facility financing, which is often provided either by raising taxes or issuing municipal bonds. ${ }^{7}$ Charter schools, however, are generally not part of a local school district and rarely have the authority to raise taxes or issue tax-exempt bonds independently. Charter schools' access to other facility financing options, such as private lending, is also limited. Charter schools are often considered credit risks because they may have limited credit histories, lack significant cash flows, and have short-term charters that can be revoked. As a result, private loans are not easily accessible to charter schools for facility financing. Because municipal bonds and private loans may be inaccessible to charter schools, many charter schools finance their facilities through per-pupil allocations provided by the state or district. These per-pupil allotments are provided to all public schools, including charter schools, to cover operating expenses, such as teachers' salaries and the purchase of books and supplies. ${ }^{8}$ Additionally, some charter schools finance their facilities through private donations.

Several states provide financial assistance to charter schools that is specifically designated for facilities. Eleven states and the District of Columbia provide direct funding to charter schools for facilities, either through grant programs to help cover building acquisition costs or leaseaid programs to help cover building maintenance and facility lease or mortgage payments. Of these 11 states, 5 - Arizona, California, Florida, Massachusetts, and Minnesota - and the District of Columbia have provided charter schools with a designated annual revenue source to offset facilities expenses. Approximately half of all charter schools operate in these 5 states and D.C., where charter schools receive a supplemental per-pupil allotment that is designated to cover facilities expenses. For example, charter schools in low-income areas in California may receive up to $\$ 750$ per student to cover lease expenses, while charter schools in Florida may receive up to approximately $\$ 1,300$ per student to offset

\footnotetext{
${ }^{7}$ Municipal bonds are tax-exempt bonds issued by a local government entity, such as a school district, city, or county.

${ }^{8}$ Per-pupil allotments provided to charter schools may not be as high as those provided to traditional public schools in the same districts.
} 
facilities costs. ${ }^{9}$ Additionally, at least 5 states - Colorado, Georgia, Missouri, North Carolina, and Texas - and the District of Columbia have enacted legislation that would enable the state bonding authorities to issue tax-exempt bonds on behalf of charter schools.

In addition to providing charter schools with funding for facilities, states may provide charter schools with other forms of facilities assistance. Eighteen states and the District of Columbia have enacted laws that allow charter schools access to vacant public buildings. The extent to which these laws enable charter schools to gain access to public buildings varies considerably both in terms of how proactive the states are in providing access and in terms of the cost of this access to charter schools. Some state laws, such as those in Alaska, simply make it legal for charter schools to operate in excess public space if it is available, while other state laws provide charter schools with preferential access to available space or mandate procedures for informing charter schools when public space becomes available. For instance, Arizona law requires that an annual list of appropriate public buildings be made available to charter schools.

Additionally, the amount charter schools must pay for this space varies. In Virginia, charter schools do not have to pay rent for available school buildings, while in Louisiana, charter schools must pay fair market value to use excess public facilities. Table 2 summarizes the various types of facility assistance provided. Appendix II provides greater detail about facilities assistance provisions in state laws.

Table 2: Major Types of Facilities Assistance Offered by States

\begin{tabular}{lr}
\hline Type of facilities assistance & Number of states \\
\hline Funding assistance for facilities & 11 and D.C. \\
\hline Issue tax-exempt bonds on behalf of charter schools & 5 and D.C. \\
\hline Access to vacant public buildings & 18 and D.C. \\
\hline Source: GAO analysis of state charter school laws.
\end{tabular}

Some federal support also exists to help public charter schools acquire facilities. ${ }^{10}$ Under the Public Charter Schools Program, the federal

${ }^{9}$ Education Commission of the States, StateNotes, Charter Schools: Charter School Finance (Denver, CO: Apr. 2003).

${ }^{10}$ Similarly, little federal funding is provided to support facilities for traditional public schools. 
government provides a limited number of grants to public or private organizations for the development of facilities-related "credit enhancement initiatives." Organizations use credit enhancement grants to leverage additional capital for charter schools for the acquisition, construction, or renovation of facilities. Charter schools do not receive this grant money directly; instead the grant money is provided to organizations that use the funding for a range of activities to help charter schools improve their credit. These activities include insuring or facilitating the issuance of bonds, subsidizing interest payments, creating a facilities loan pool, or serving as a loan guarantor. Grant recipients generally provide support to charter schools in specific states or regions or to specific types of charter schools. For example, one 2001 grant recipient, the Raza Development Fund, a nonprofit Hispanic advocacy organization, is using its grant to increase 30 Hispanic charter schools' access to direct loans. The credit enhancement program has received funding twice, in fiscal years 2001 and $2003 .{ }^{11}$ Under the Public Charter Schools Program, the federal government is also authorized to provide grants to states to establish or enhance per-pupil facilities aid programs; however, as of July 2003, this program has never received funding. Like traditional public schools, charter schools may access federally administered Qualified Zone Academy Bonds (QZAB), which provide financial assistance for public school renovations. To qualify for these bonds, public schools must be located in an empowerment zone or enterprise community ${ }^{12}$ or have at least 35 percent of their students eligible for free or reduced-price school lunch. In addition, federal law permits local school districts, including charter schools, to enter into publicprivate partnerships that allow private entities to take advantage of taxexempt bonds - often referred to as private activity bonds-for school construction and renovation. However, as we reported in a 2000 study of charter school facilities financing, the credit worthiness of most new

\footnotetext{
${ }^{11}$ In both fiscal years 2001 and 2003 , the program received $\$ 25$ million. From the fiscal year 2001 funding, Education awarded five grants, ranging between $\$ 3$ million and $\$ 6.4$ million. The five grant recipients will provide credit enhancement programs to charter schools in at least 10 states and the District of Columbia. Education expects to award grants of similar values for the fiscal year 2003 funding.

${ }^{12}$ Empowerment zones and enterprise communities are communities with high levels of poverty that participate in the U.S. Department of Agriculture's community empowerment program, which provides tax benefits to help communities meet long-term strategic goals regarding private investment and job creation.
} 
charter schools and concerns about their ability to repay remain a concern for bond raters and buyers. ${ }^{13}$

Obtaining Sufficient StartUp Funding Is also a Major Challenge; Assistance Provided Primarily by Federal Programs
According to national studies of new charter schools, obtaining sufficient start-up funding is one of the two greatest challenges facing charter schools during the planning and early implementations stages. Charter schools incur many start-up expenses during the planning and early implementation stages, such as hiring lawyers and business consultants to review charter plans and applications, buying curriculum programs and instructional materials, purchasing school furniture and supplies, hiring key staff, purchasing insurance, and placing down payments on facilities. Unlike traditional public schools, most charter schools do not receive financial support from local school districts during the early planning stages, and many are not eligible for local funds until the school opens. While the timetable for disbursing funds varies by location, charter schools can incur a variety of expenses-for example, attorney and consultant fees-before they are eligible to receive most sources of public funding. To help meet these early expenses, many charter schools rely on funds raised through private sources, such as individual fundraising or awards from private foundations.

Charter schools become eligible for financial assistance under the Public Charter Schools Program after the application has been submitted and certain other requirements met. Through this program, charter schools can receive funding to help defray planning, design, and implementation expenses. Grants are awarded under this program by Education to state departments of education to be distributed directly to charter schools for a period of not more than 3 years, of which no more than 18 months may be used for planning and program design and no more than 24 months may be used for implementation..$^{14}$ Education recommends that states provide charter schools with $\$ 450,000$ over the 3-year period to be distributed in

\footnotetext{
${ }^{13}$ See U.S. General Accounting Office, Charter Schools: Limited Access to Facility Financing, GAO/HEHS-00-163, (Washington, D.C.: Sept. 12, 2000), 20.

${ }^{14}$ The state departments of education in Arizona, New Hampshire, and Wyoming do not participate in the Public Charter Schools Program. Charter schools in states not participating may apply directly to the U.S. Department of Education for 3-year grants under this program.
} 
$\$ 150,000$ annual allotments. ${ }^{15}$ Charter schools that are still in the early planning stages and have not yet submitted an application may apply for a waiver to the program's eligibility requirements to receive a "pre-planning" subgrant. Education recommends that states awarding pre-planning subgrants provide sums of $\$ 10,000$ to $\$ 20,000$ and requires that preplanning grants count towards a charter school's 3-year subgrant time limit. According to an evaluation of the Public Charter Schools Program conducted for Education in 2001, ${ }^{16}$ almost two-thirds of charter schools are recipients of Public Charter School subgrants. The data also indicated that of those schools not receiving subgrants through the Public Charter Schools Program, about half did not apply. According to Education officials, charter schools that are turned down for subgrants through this program may have applied for the funding after they had completed their early planning and implementation stages, which would make them ineligible.

An analysis of data collected by the Education Commission of the States showed that in 2003 approximately one-fourth of states with charter school laws had established programs to assist new charter schools with start-up costs through grants or loans. Nine states, Alaska, California, Georgia, Illinois, Louisiana, Minnesota, New Mexico, Oklahoma, and Pennsylvania, and the District of Columbia made start-up loans ${ }^{17}$ or grants available to new charter schools. The size and timing of these grants and loans varied from state to state. In Georgia, for example, new charter school founders were eligible for $\$ 5,000$ grants during the school planning phase, while new charter school founders in Pennsylvania were eligible for $\$ 25,000$ grants to cover expenses during the charter application process. Additionally, Louisiana had established a $\$ 3$ million loan fund to provide charter schools with money during the start-up period, and charter schools in California are eligible to receive loans for as much as $\$ 250,000$, which could be repaid over a 5-year period. Although these grant and loan

\footnotetext{
${ }^{15}$ In addition to providing subgrants to charter schools, a state may dedicate up to 10 percent of its Public Charter Schools grant to establish a charter school revolving loan fund. Through this fund, participating states provide new charter schools with loans to offset initial operating expenses. The terms of these loans are determined by state education agencies.

${ }^{16}$ SRI International, Policies and Program Studies Service, U.S. Department of Education, A Decade of Public Charter Schools, Evaluation of the Public Charter Schools Program: 2000-2001 Evaluation (Washington, D.C.: Nov. 2002).

${ }^{17}$ We were unable to determine if these start-up loans were funded through the Public Charter Schools Revolving Loan Program or state funds.
} 
programs had been authorized, funding for these programs is uncertain. For example, Minnesota will not fund its charter school start-up grant program for fiscal year 2004 for budgetary reasons. Additionally, according to the Education Commission of the States data, Nevada, which has authorized a loan program, has never funded it.

\section{Lack of Specific Expertise also Poses Difficulties; Some Assistance Is Available from Local or Nonprofit Sources}

The wide array of knowledge and skills necessary to open and operate a charter school often presents a challenge for charter school founders. For instance, according to charter school advocates with whom we spoke many charter school founders may have extensive educational experience but limited knowledge of legal and business issues. In order for a charter school to be successful, charter school founders must coordinate a wide range of activities: planning the school's educational system and curriculum, hiring leadership and teaching staff, assembling a board of directors, ensuring the school's compliance with all laws and regulations, locating and acquiring school facilities, creating the school's budget and accounting systems, and managing the day-to-day operations of the school. As figure 2 shows, to successfully achieve these tasks, charter school founders must have expertise in a variety of areas, including educational systems, legal issues, and general business practices; however, few individuals are well versed in all of these subjects. National surveys of charter school founders cite their limited knowledge of certain areas as a challenge to opening new charter schools. 
Figure 2: Expertise Needed to Open a Charter School

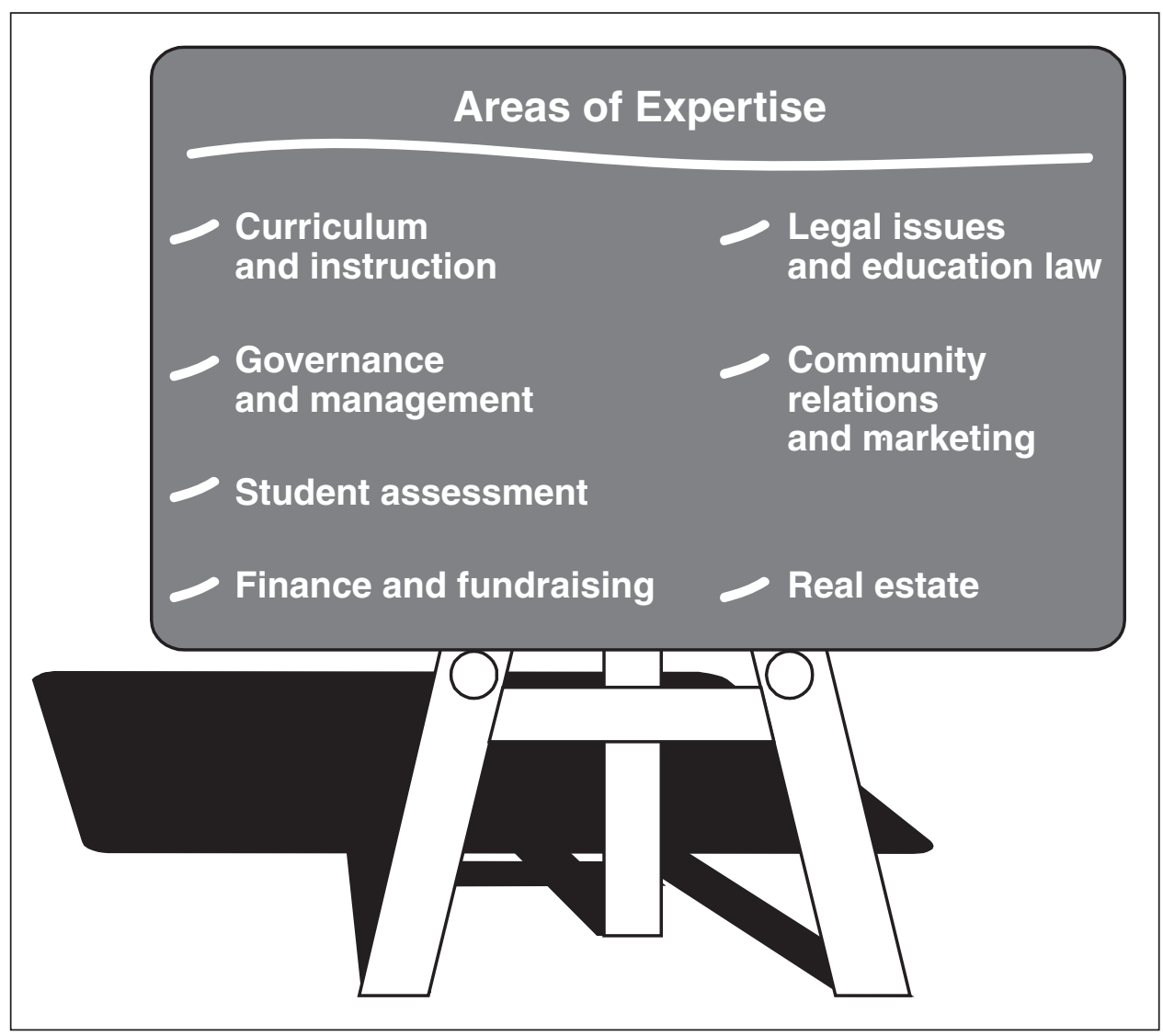

Sources: Art Explosion (image); www.uscharterschools.org (text).

The federal government provides limited assistance to charter school founders to help them acquire expertise. Education sponsors a Web site, www.uscharterschools.org, that provides an overview of state charter laws, lists state charter school advocacy groups, and promotes exchanges between charter school founders. In addition, 5 percent of the Public Charter Schools Program grant money may be used by the states to cover administrative expenses, which can include funding for technical assistance programs. For example, the Florida Department of Education uses a small percentage of its approximately $\$ 26$ million Public Charter Schools grant to fund a resource center that provides new charter schools with technical assistance throughout the chartering process. The Florida program provides charter schools with assistance in management, governance, and budgeting and fosters mentoring relationships between new and established charter schools. Under the Public Charter Schools 
Program, some states provide subgrants to high-performing charter schools that have been open for at least 3 consecutive years to share best practices with new charter school founders.

Technical assistance programs that help charter school founders learn more about how to open and operate a school are generally administered by state or local governments. According to the Education Commission of the States, 28 states and Puerto Rico provide some technical assistance to charter schools through their state departments of education or local school boards. The extent and type of this assistance varies. Some states conduct periodic workshops, others provide targeted assistance to individual charter schools upon request, and some states provide both types of assistance. For example, the Pennsylvania Department of Education conducts monthly regional workshops and provides assistance to individual charter schools upon request. Additionally, states or local school boards may provide charter school founders with assistance during the charter application period or after the charter school has opened. Types of assistance that are designed to help charter school founders operate their schools include staff development and management, use of student data, technology training, and curriculum development.

Charter school founders also rely on nonprofit organizations to help them gain expertise. Charter school resource centers, which are primarily nonprofit organizations, assist charter schools in specific states or regions in the opening and operation of the school. According to data from a national charter school advocacy organization, these resource centers operate in approximately half of the states with charter school laws. The resource centers address founders' lack of expertise by providing new charter schools with a wide range of services, such as budgeting assistance, board development, and classroom management. The type of services provided by these resource centers varies significantly. For example, a charter school resource center in Wisconsin helps charter schools with board development, networking, business management, and legal compliance. The Massachusetts Charter School Resource Center provides a fellowship to a small number of charter school founders. Charter school founders selected to participate in this competitive program are paid $\$ 50,000$ for 1 year, as they learn how to effectively found and operate a charter school through a training and internship program. According to resource center representatives with whom we spoke, charter school resource centers also may help potential founders make decisions about moving forward with the application and chartering process. By helping potential charter school founders better understand what is involved with founding a new charter school, resource centers can 
also offer potential founders advice as they decide whether or not they should attempt to open a charter school. The funding and operation of charter school resource centers also varies significantly. Charter school resource centers may be funded by private donations, supported by feefor-service arrangements, sponsored by university programs, or financed by state or local governments.

In addition to more formal resources, charter school founders rely on other charter school founders and their own boards of directors to help them gain needed expertise. Charter school founders often rely upon other charter school founders who had opened schools in the same state or region for expertise and advise. One charter school founder we interviewed said that the insights and expertise provided by people who had also gone through the local chartering process enabled him to more fully understand what was required to charter and open a school.

Additionally, charter school founders seek expertise and assistance from their boards of directors. As nonprofit organizations, all charter schools must have a board of directors responsible for school governance issues. Charter school boards often include members with varying areas of expertise, such as lawyers, accountants, management consultants, and community organizers. Founders, therefore, have an additional resource available to assist them with issues that may be outside of their own area of expertise.

District of Columbia Charter Schools Face Similar Challenges, but More Facilities Assistance Is Available
Charter school founders in the District of Columbia, like charter schools nationwide, face challenges with facilities, start-up funding, and expertise, and except for receiving greater assistance with funding facilities, have generally similar resources. Although D.C. charter schools receive greater facilities assistance, charter school founders report that real estate costs and the current unavailability of public buildings make securing appropriate buildings difficult. New charter schools in the District also report incurring substantial costs early in the design and planning stages and cite obtaining start-up funding as a significant challenge to starting a new charter school. However, in addition to design and planning funds available through the Public Charter Schools Program, new charter schools in the District can receive partial access to local funds prior to the opening of the school. Finally, new charter school founders in the District reported that developing the expertise needed to successfully open and operate a charter school presents a problem that has been exacerbated by the recent closing of the nonprofit organization, the D.C. Charter School Resource Center. 


District Charter Schools
Have Additional Resources
to Address Facilities
Problem, but Real Estate
Costs in the District
Continue to Limit Options

According to D.C. charter school founders and other knowledgeable sources with whom we spoke, securing appropriate facilities is the greatest challenge to opening a charter school in the District. Charter school officials and charter school authorizing officials told us that in recent years the expense of real estate in the District of Columbia has limited the options available to new charter schools. National reports on commercial real estate markets show that commercial property in the District is among the most expensive in the nation and that there is continued strong demand for commercial property. Additionally, D.C. charter school founders reported that available buildings tend to be older, in need of extensive and costly renovations, or not fit to be used as schools. For example, one charter school organization that purchased an unoccupied District of Columbia Public Schools (DCPS) building estimated that the cost of renovating the building would be over $\$ 5$ million.

To help alleviate some of this strain, the D.C. charter school law provides charter schools with a limited preference in acquiring surplus DCPS buildings. ${ }^{18}$ Specifically, the law provides charter schools with a preference to purchase or lease DCPS surplus buildings at below market rates, provided that doing so will not result in a significant loss of revenue that might be obtained from other dispositions or use of the property. In March 2000, DCPS conducted an inventory of all its schools and designated 38 surplus school buildings. As of June 2003, charter schools are using 14 of these buildings: 11 set aside for their exclusive use by order of the mayor in October 2000 and 3 others. ${ }^{19}$ According to District officials, of these 14 buildings, charter school groups have purchased, or are in the process of purchasing, about half at a 25 percent discount from fair market value. ${ }^{20}$ The other half are being leased to charter schools at discounted rates-about 50 percent of fair market value. As of June 2003, DCPS had designated no additional surplus buildings. However, as a part of its Facilities Master Plan, a comprehensive plan for renovating or

\footnotetext{
${ }^{18}$ Surplus buildings are those not needed for educational purposes by DCPS. They are referred to the Mayor's office for final disposition.

${ }^{19}$ According to DCPS officials, some of these buildings were occupied by charter schools prior to the Mayor's order and some charter schools have negotiated long-term leases in DCPS school buildings that were not in the order.

${ }^{20}$ According to District officials, fair market value is based on the building's use as a school. Charter schools that purchased buildings valued at over $\$ 1,000,000$ received a 15 -percent discount.
} 
modernizing its schools, DCPS is currently finalizing a facilities assessment. This assessment, which DCPS expects to complete by September 2003, could potentially identify additional surplus school buildings. ${ }^{21}$ If such buildings were identified, a list of them would be sent to the mayor's office, which would determine how to dispose of them.

In addition to these preferences, DCPS designated one of its public school buildings as a "hub school," where charter schools can lease space for up to 3 years. Since 1998, the hub school has housed a total of 6 charter schools, 3 charter schools at a time, with each charter school occupying its own floor. All the schools in the building share common space, such as the auditorium, gymnasium, and outdoor field space. The two authorizing boards notify charter schools when space in the hub school becomes available, and charter schools can submit an application to the Mayor's Office of Property Management for consideration.

In addition to the hub school, DCPS occasionally provides charter schools with other temporary space. It provides such space when a DCPS school is not using part of the building it occupies or when DCPS has a vacant building that it has not designated as surplus. In such cases, DCPS allows charter schools to lease the space on a year-to-year basis. According to an official in the DCPS realty office, 2 charter schools rented excess space in an occupied DCPS school building under this type of agreement in school year 2002-2003. Currently, DCPS has no formal process for making temporary space available to charter schools. In providing charter schools with temporary space, the District and DCPS meet some needs particular to charter schools. Specifically, the hub school and the DCPS temporary space allow charter schools, which are often initially smaller than traditional schools, to benefit from the economies of scale realized by sharing space, such as cafeterias and gymnasiums, with another school. Temporary space also allows charter schools to focus on the educational component of their school first rather than focusing on finding a permanent facility.

Recent legislation increased the potential for additional shared space arrangements. This legislation requires DCPS to present a plan to the City Council for the co-location of charter and other public schools where

${ }^{21}$ DCPS officials told us that not all vacant buildings are considered surplus, as some are needed to temporarily house students displaced from buildings undergoing renovations and some are reserved for future use. 
underutilized DCPS space exists. ${ }^{22}$ As of July 2003, the co-location plan had not been completed, but DCPS was finalizing a use and capacity study of all its school buildings, which should identify any underutilized space that currently exists.

In addition to the District, two nonprofit organizations have provided D.C. charter schools with assistance in sharing facilities. The Appletree Charter School Incubator-a charter school start-up facility operated by a nonprofit organization-provided temporary space to 2 District charter schools between 1998 and 2002. The Appletree Institute rented space in a federally leased building at a discount for 4 years and then provided space to District charter schools at a discounted rate. The Incubator closed when the lease expired in 2002 and as of June 2003, both schools were leasing space in other buildings. In 2003, another nonprofit group, the Charter Schools Development Corporation (CSDC), ${ }^{23}$ purchased a surplus DCPS building ${ }^{24}$ which it is renovating and will use to permanently house 2 charter schools, according to a CSDC official.

Besides providing some access to facilities, the District of Columbia also provides financial assistance to help charter schools acquire facilities through a variety of mechanisms. One of these is a per-pupil facilities allotment. In addition to a per-pupil allotment that covers operating expenses, District charter schools receive a per-pupil allotment for facilities expenses. In the 2002-2003 school year, charter schools in the District received a facilities allotment of approximately $\$ 1,600$ per pupil for traditional students and about $\$ 3,600$ per pupil for students at public charter boarding schools. ${ }^{25}$

\footnotetext{
${ }^{22}$ See D.C. Code 38-1851.

${ }^{23} \mathrm{CSDC}$ is a nonprofit organization that has provided financing assistance, primarily through a Credit Enhancement Program, to charter schools across the country for 6 years.

${ }^{24}$ CSDC purchased the Kingsman School building in 2003. The Kingsman school was included as one of the 38 buildings deemed as a surplus building by DCPS in 2000 .

${ }^{25}$ The $\$ 1,600$ per-pupil facilities allotment is in addition to the approximately $\$ 6,500$ per pupil given to charter schools for their operating expenses. The $\$ 6,500$ figure is a base amount and is adjusted upwards according to grade level, special education status, and language proficiency.
} 
Another way the District provides financial support for facilities to charter schools is through its Credit Enhancement Revolving Fund. ${ }^{26}$ Under the authority of the D.C. Department of Banking and Financial Institutions, this program provides loan guarantees and collateral to help finance the purchase or new construction of charter school facilities. The Credit Enhancement Revolving Fund was first appropriated $\$ 5$ million in fiscal year 2000. It was not until 2003 that it received its second appropriation totaling $\$ 8$ million. To date, the Credit Enhancement Revolving Fund has been able to enhance 6 charter school loans.

In addition to the Credit Enhancement Revolving Fund, in fiscal year 2003 , the District allocated $\$ 5$ million to a new direct-loan program. Under this program, the District can provide low-interest loans directly to charter schools, rather than through private lenders. Charter schools can use the proceeds from these loans as collateral for a larger loan on a purchase, new construction, or renovation of a building. This program will potentially benefit new charter schools the most because private lenders often do not lend to charter schools that have not begun operating. District officials told us that as of August 2003, the District has obligated funds from the direct loan program to 7 charter schools for varying amounts, but the loan process has not yet been completed.

The District also provides financial assistance to help charter schools acquire facilities by allowing charter schools to raise revenues through tax-exempt bonds. The District will issue bonds on behalf of charter schools if the charter school meets certain eligibility requirements, including that the charter school holds nonprofit status, has sufficient collateral, and has been operating as a school for at least 2 years. According to the D.C. official overseeing the bond program, new charter schools have not been able to benefit from this source of funding because they have not been operating long enough to qualify. As of August 2003, the District has issued 7 bonds on behalf of 6 charter schools, which has allowed District charter schools to borrow over $\$ 39.4$ million

\footnotetext{
${ }^{26}$ This Credit Enhancement Revolving Fund is separate from the credit enhancement initiatives under the federal Public Charter Schools Program. The federal program awarded grants with fiscal year 2001 funding to five nonprofit organizations, two of which specify that they plan to assist D.C. charter schools with obtaining credit.
} 
in bond revenues to use for their facilities. ${ }^{27}$ One additional charter school has a bond issue pending.

In addition to tax-exempt bonds, two other federal bond programs are available to both traditional schools and charter schools in the districtQZAB and private activity bonds. According to District officials, as of June 2003, no charter schools had applied for either of these programs.

Figure 3 shows a summary of the kinds of facility assistance received by D.C. charter schools operating during the 2002-2003 school year. Some of this assistance was received at start-up, such as temporary housing in the hub school, some was received after start-up, for example, tax-exempt bonds for facilities, and some is received on an on-going basis, for example, the per-pupil facilities allotment received by all schools. For a list of charter schools operating in the District in the 2003-2003 school year and their facility status, see appendix III.

${ }^{27}$ All 6 bonds have been purchased by private entities, such as Bank of America and SunTrust, and are not available for purchase on the open market. As such, they have not been rated for credit risk. 
Figure 3: Kinds of Facilities Assistance Provided through the District to Charter Schools Operating during School Year 2002-2003

\begin{tabular}{|l|l|}
\hline Resource & Number of charter schools ${ }^{\mathrm{a}}$ \\
\hline Per-pupil facilities allotment & \\
\hline $\begin{array}{l}\text { Occupying (or previously } \\
\text { occupied) space in a } \\
\text { DCPS building at start-up }\end{array}$ & \multicolumn{1}{|l}{19} \\
\hline Direct loan & \multicolumn{1}{|c|}{6} \\
\hline Tax-exempt bonds & 6 \\
\hline Credit enhancement & 6 \\
\hline
\end{tabular}

Source: GAO synthesis of information given by D.C. government officials and charter school authorizers.

${ }^{a}$ These numbers are current as of school year 2002-2003 and schools can benefit from multiple resources.

${ }^{\mathrm{b}}$ The direct loan program has obligated its funds to 7 charter schools, but has not completed distributing funds.

The District, Like a Few States, Provides Early Access to Funds to Lessen Start-Up Funding Issues
Like new charter schools in other parts of the country, new charter schools in the District also incur high start-up costs early in the design and planning stages. A variety of District charter school founders and others knowledgeable about charter school issues said that there were limited options for obtaining start-up funding to plan a new school, but that once the charter application was approved, more funding options became available. The D.C. Public Charter School Board and the D.C. Board of Education have similar application processes, which usually start over a year before the school's intended opening. Figure 4 shows a typical timeline, including when a charter school might expect to become eligible for public funds. Charter schools in the District must apply for their charter by June for the school year that starts in September of the following year. Between July and August, both chartering boards hold public hearings to ask questions of the charter schools and to allow the community to provide input on the charter school. In August, preliminary decisions are made on the charter. At that point, charter applications receive a preliminary approval, a full approval, or a denial. According to 
officials from both authorizing boards, many of their applications receive a preliminary approval before a full approval. ${ }^{28}$

Figure 4: Timeline of D.C. Public Chartering Process and Eligibility for Public Funds

Eligibility for public funds

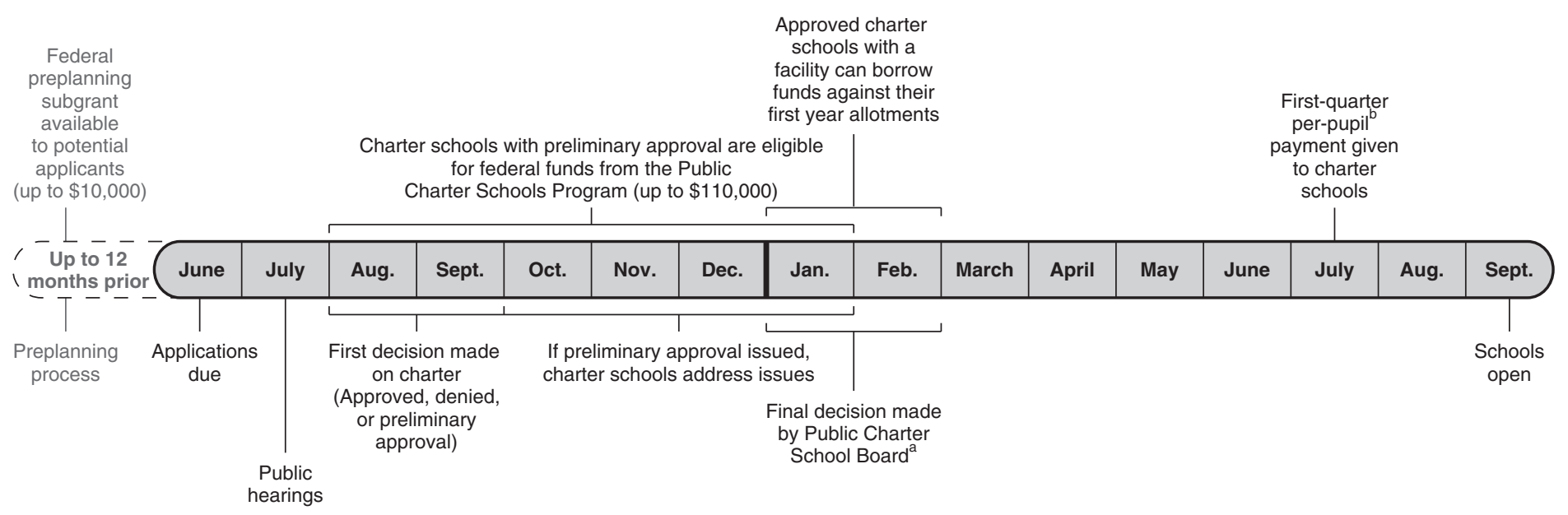

\section{Chartering process}

Source: GAO analysis of charter school authorizers documents. ${ }^{a}$ The D.C. Board of Education does not have a specific date for making final decisions, as those
decisions are made on a case-by-case basis.

${ }^{\mathrm{b}}$ This payment consists of both the per-pupil facilities allotment and the per-pupil operational allotment.

Until fiscal year 2003, charter schools were not eligible for public funds prior to receiving preliminary approval. As a result, charter schools relied on private sources of funding to cover their expenses. For example, one recently approved charter school founder reported spending close to $\$ 200,000$ in private foundation funds during the early planning stages of the charter school to pay for fees and feasibility studies on a facility she planned to use for her charter school. Another charter school founder said that he had to take out a personal loan to put a deposit on a facility. Charter school founders said that early funds would be helpful in paying

\footnotetext{
${ }^{28}$ To receive full approval, it is required that charter schools secure a facility. According to officials from the charter school authorizing boards, this is the most difficult part of the application process.
} 
for such things as compensation for the time professionals spent on writing the charter application and initial inspections of facilities.

Beginning in fiscal year 2003, D.C. began awarding pre-planning subgrants for up to $\$ 10,000$ from its federal Public Charter Schools Program grant, making some funds available earlier in the process. ${ }^{29}$ Potential charter school applicants can obtain these grants prior to the submission of the charter application. The D.C. program specifies that these funds may be used for up to 12 months of pre-planning activities, such as the professional development of the charter school planning team and informing the community about the school. In fiscal year 2003, nine D.C. charter school groups received these grants.

D.C. charter school applicants that have received preliminary approval are eligible to apply for Public Charter Schools Program subgrants for up to $\$ 110,000$ to be used the first year following preliminary approval. In the second and third years, charter schools can receive subgrants in amounts from $\$ 95,000$ to $\$ 200,000$ to be used for implementation purposes. In fiscal year 2003, DCPS awarded 4 first-year subgrants for $\$ 110,000$ each and 5 second/third year subgrants for $\$ 200,000$ each. Applicants can apply for one or all of these subgrants - pre-planning, first, second, and third yearbut the total period of time in which these funds are received cannot exceed 36 months.

The District also provides charter schools with access to some local funds - a short-term loan against their annual funds and early payment of their first-quarter funds - after the charter is fully approved and prior to the schools opening. To receive either type of funding, schools must have obtained full approval of their charter, secured a facility, and hold nonprofit status. According to District officials, no charter schools have applied for the short-term loan in the past 3 years because the District changed its policy and now disburses its first-quarter payment in July, approximately 6-8 weeks prior to the start of the school year. The timeline for receiving the first-quarter payment is now consistent with when many charter schools can meet the eligibility requirements for receiving this loan.

\footnotetext{
${ }^{29}$ The DCPS Office of Federal Grant Programs administers federal funding opportunities for charter schools authorized by the DCPS Board of Education and the District of Columbia Charter School Board.
} 
The District Charter School Resource Center's Closing Has Diminished Access to Start-Up Knowledge, although Some Local Resources Are Available
New charter school founders in the District are similar to charter school founders across the country in that they must have expertise in a wide range of areas to successfully open and operate a charter school. In our discussions, some D.C. charter school experts said that one of the challenges that many charter school founders encounter is acquiring the business and legal knowledge necessary to run a school. D.C. charter school experts said that many charter school founders have a vision for the education they want to provide their students but do not always know how to manage the many tasks involved with administering a school. To address this issue, the District chartering authorities provide some assistance with the application and other technical assistance to school founders during the chartering process. However, this support is often limited to assisting charter school groups with the application process and does not always include support once the application has been approved. For this reason, many charter schools turn to private and nonprofit resources to assist them with these issues.

The nonprofit D.C. Charter School Resource Center offered assistance to charter school groups until it closed in the spring of 2003. According to individuals familiar with the D.C. resource center, since 1998 it offered classes on how to fill out the charter application and put charter school groups in contact with organizations that would potentially provide some monetary assistance.$^{30}$ Local charter school advocates told us that the nonprofit D.C. Charter School Resource Center's recent closing has limited the amount of assistance available to help new charter schools founders acquire necessary expertise.

\section{Concluding Observations}

The clear consensus among those with whom we spoke and in the literature we reviewed was that start-up funds and obtaining an adequate facility remain significant obstacles for charter schools, especially in those locations like the District of Columbia, where the cost of and demand for property is high. Relative to charter schools in many other locations, District charter schools benefit from a greater variety of facilities-related support, such as a per-pupil facility allowance and preference to surplus school buildings. In addition, recent steps taken to identify surplus property and underutilized school buildings have potential for making additional space available to charter schools. However, although the law

\footnotetext{
${ }^{30}$ We were unable to contact officials from the D.C. Resource Center, as the Center closed during the time of our review.
} 
provides for giving charter schools a limited preference in acquiring surplus DCPS property, it also contains the stipulation that the preference is only to be given provided that doing so will not result in a significant loss of revenue that might otherwise be obtained.

Agency Comments and Our Evaluation
We provided a draft of this report to the Department of Education for its review and comment. Education's Executive Secretariat confirmed that Education officials had reviewed the draft and found the information in the draft to be helpful. Education officials had no comments except for a few technical clarifications, which we incorporated as appropriate in this report.

We also provided a draft of this report to officials at both of the D.C. charter school authorizing bodies - the D.C. Board of Education and the D.C. Public Charter School Board. In addition, we provided portions of the draft report pertaining to the District of Columbia to officials from D.C. Public Schools, the Executive Office of the Mayor, the Department of Banking and Financial Institutions, and the Office of the Chief Financial Officer. Officials from these offices provided technical comments, which we incorporated as appropriate in this report.

We are sending copies of this report to the Secretary of the Department of Education, relevant congressional committees, relevant District of Columbia officials, and other interested parties. We will also make copies available to others upon request. In addition, the report will be available at no charge on GAO's Web site at http://www.gao.gov. Please contact me at (202) 512-7215 if you or your staffs have any questions about this report. Other major contributors to this report are listed in appendix V.

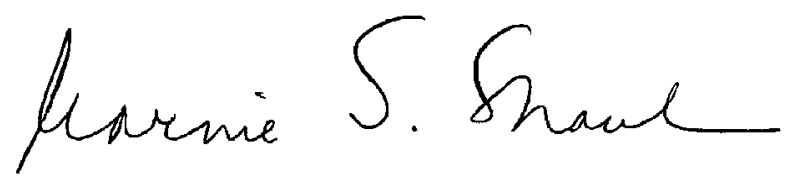

Marnie S. Shaul

Director, Education, Workforce, and Income Security Issues 


\section{Appendix I: Scope and Methodology}

To obtain information about the challenges faced by charter school startups across the country and the resources available, we analyzed federal and state charter school laws. We conducted interviews with U.S. Department of Education officials, charter school policy experts, and charter school advocates in various states. Specifically, we interviewed representatives from the Charter School Friends National Network, the Progressive Policy Institute, and other advocacy and research groups. We also interviewed representatives from charter school resource centers in some states-Florida, Massachusetts, Minnesota, Pennsylvania, Tennessee, and Wisconsin-that were identified as having proactive resource centers by those knowledgeable about charter schools. We also conducted a review of all state laws on charter school facilities. We reviewed the Department of Education's 4-year studies on the state of charter schools and Education's Public Charter Schools Program evaluation. Additionally, we analyzed Education Commission of the States data published in the Collection of Charter School ECS StateNotes.

To obtain information about charter schools in the District of Columbia, we analyzed District of Columbia and federal laws affecting charter schools in the District. We interviewed officials from the District of Columbia Board of Education Public Charter Schools Oversight Office, the District of Columbia Public Charter School Board, the District of Columbia Public Schools, and several other D.C. government offices, including the Executive Office of the Mayor, the Department of Banking and Financial Institutions, and the Office of the Chief Financial Officer. We conducted a discussion group consisting of District representatives from charter school advocacy groups, researchers, charter school founders, and other individuals knowledgeable of charter school issues in the District of Columbia. We also interviewed founders of D.C. charter schools, as well as other representatives from the D.C. charter school community, including the AppleTree Institute, Friends of Choice in Urban Schools (FOCUS), and the Charter Schools Development Corporation. We also visited César Chávez Public Charter High School for Public Policy, 1 of the 39 charter school campuses in the District. 


\section{Appendix II: Charter School Facility Assistance Provisions, as of July 2003}

\begin{tabular}{|c|c|}
\hline State & State requirements pertaining to facility assistance for charter schools. \\
\hline Alabama & $\mathrm{N} / \mathrm{A}$ \\
\hline Alaska & $\begin{array}{l}\text { Law permits operation of schools in existing school district facilities upon approval of district's administrative } \\
\text { staff. }\end{array}$ \\
\hline Arizona & $\begin{array}{l}\text { State has a "stimulus fund" which provides financial support for start-up costs and costs associated with } \\
\text { facilities' renovations or remodeling. The Arizona Department of Education must publish an annual list of } \\
\text { existing vacant and unused buildings, and unused portions of buildings available to charter schools. (No } \\
\text { lease/purchase preference is given to charter schools.) }\end{array}$ \\
\hline Arkansas & No facilities assistance provisions. \\
\hline California & $\begin{array}{l}\text { State has established a "Charter School Facilities Account" funded by bond proceeds (K-12). Additionally, the } \\
\text { state has set up a charter school facility grant program for charter schools located in low-income areas which } \\
\text { awards up to } \$ 750 \text { per student to provide assistance for up to } 75 \text { percent of the charter school's annual } \\
\text { facilities rent and lease costs. Each school district must make any vacant school facilities available to charter } \\
\text { schools at minimum charge. }\end{array}$ \\
\hline Colorado & $\begin{array}{l}\text { Charter schools must be able to use district facilities "deemed available" by the school district at no cost, except } \\
\text { for operations and maintenance expenses. The state must distribute a portion of its education funds to charter } \\
\text { schools to help cover capital construction costs. A charter school may ask its local school board to issue bonds } \\
\text { to fund capital construction expenses. }\end{array}$ \\
\hline Connecticut & $\begin{array}{l}\text { State has established a grant program that provides charter schools with up to } \$ 500,000 \text { for assistance with } \\
\text { capital expenses; to be eligible, the charter school must have been operating during the prior fiscal year. }\end{array}$ \\
\hline Delaware & $\begin{array}{l}\text { School districts must make unused buildings or space available for charter schools, and must "bargain in good } \\
\text { faith" over the cost of rent, services, and maintenance. The Delaware Department of Education must publish an } \\
\text { annual list of facilities available for charter school use. }\end{array}$ \\
\hline District of Columbia & $\begin{array}{l}\text { District of Columbia offers charter schools a limited preference to lease or purchase surplus public school } \\
\text { buildings provided that doing so will not result in a significant loss of revenue that might be obtained from other } \\
\text { dispositions or uses of the facility or property. An "enhanced credit fund" has also been established to help } \\
\text { charter schools finance the purchase, construction, and/or renovation of facilities. District charter schools also } \\
\text { receive an annual per-pupil facilities allowance. }\end{array}$ \\
\hline Florida & $\begin{array}{l}\text { State agencies may issue revenue bonds to provide for charter school facilities assistance. Charter schools are } \\
\text { also eligible for facilities assistance from a state capital outlay fund. Charter schools are offered a preference to } \\
\text { use surplus school buildings. }\end{array}$ \\
\hline Georgia & $\begin{array}{l}\text { Georgia State Board of Education may require a local referendum to decide whether a local board of education } \\
\text { must provide funds from school tax levies or incur bonded indebtedness or both, to support a charter school. }\end{array}$ \\
\hline Hawaii & $\begin{array}{l}\text { State oversees annual maintenance and repairs for charter school facilities and establishes a priority-of-need } \\
\text { list for charter school facilities requiring assistance. }\end{array}$ \\
\hline Idaho & A charter school's board of directors may borrow money to finance the purchase of facilities for charter schools. \\
\hline Illinois & $\begin{array}{l}\text { A charter school may negotiate and contract with a school district, a state college or university, or any other } \\
\text { public, nonprofit, or for-profit entity for a school charter site. If a charter school uses an existing school building, } \\
\text { the school is only required to pay the building operation and maintenance costs-no rent is required. }\end{array}$ \\
\hline Indiana & No facilities assistance provisions. \\
\hline lowa & No facilities assistance provisions. \\
\hline Kansas & No facilities assistance provisions. \\
\hline Kentucky & $\mathrm{N} / \mathrm{A}$ \\
\hline Louisiana & $\begin{array}{l}\text { Local school boards must make any vacant facility available to charter schools at fair market value. Facilities } \\
\text { that were constructed at no cost to the school board must be provided to the charter school at no cost. }\end{array}$ \\
\hline
\end{tabular}




\begin{tabular}{|c|c|}
\hline State & State requirements pertaining to facility assistance for charter schools. \\
\hline Maine & N/A \\
\hline Maryland & No facilities assistance provisions. \\
\hline Massachusetts & $\begin{array}{l}\text { Massachusetts funds charter schools on a per-pupil basis. As part of this payment, the state includes the } \\
\text { charter school's cost of leasing a facility, as well as facility maintenance and operation expenses, in the } \\
\text { payment. }\end{array}$ \\
\hline Michigan & No facilities assistance provisions. \\
\hline Minnesota & $\begin{array}{l}\text { The state provides building lease aid grants to charter schools. A charter school may lease space from an } \\
\text { eligible charter school sponsor or from another public or private nonprofit nonsectarian organization. }\end{array}$ \\
\hline Mississippi & No facilities assistance provisions. \\
\hline Missouri & $\begin{array}{l}\text { A state school district may incur bonded indebtedness or "take other measures" to provide for physical facilities } \\
\text { and other capital items to charter schools that it sponsors or contracts with. }\end{array}$ \\
\hline Montana & $\mathrm{N} / \mathrm{A}$ \\
\hline Nebraska & $\mathrm{N} / \mathrm{A}$ \\
\hline Nevada & No facilities assistance provisions. \\
\hline New Hampshire & $\begin{array}{l}\text { Charter schools and their "host" school district are encouraged to enter into "mutually advantageous" } \\
\text { contracting relationships resulting in the sharing of facilities. A charter school is not eligible for facility } \\
\text { assistance unless the school is leasing a building owned by the school district, and the lease does not include } \\
\text { an option to purchase the building. }\end{array}$ \\
\hline New Jersey & No facilities assistance provisions. \\
\hline New Mexico & $\begin{array}{l}\text { Charter schools are not required to pay rent for available school district facility space. New Mexico has } \\
\text { established a "Charter School Stimulus Fund" for the initial costs of renovating and remodeling existing } \\
\text { buildings. }\end{array}$ \\
\hline New York & $\begin{array}{l}\text { State must publish an annual list of available state buildings for use by charter schools. State established a } \\
\text { charter school "stimulus fund" for acquisition, renovation, and construction of charter school facilities. }\end{array}$ \\
\hline North Carolina & $\begin{array}{l}\text { If a charter school that has applied for approval to the State Board of Education is unable to find a building, the } \\
\text { Board can approve the charter school to operate in an "adjacent local school administrative unit" for one year. } \\
\text { At the request of a charter school, a school district must lease "any" available building or land to the charter } \\
\text { school, unless the lease is not economically practical or feasible, or the district does not have adequate } \\
\text { classroom space to meet its enrollment needs. A school district may lease a building to a charter school free of } \\
\text { charge, except for maintenance and insurance expenses. North Carolina Capital Facilities Finance Agency (or } \\
\text { its successor) may issue bonds on behalf of charter schools. }\end{array}$ \\
\hline North Dakota & $\mathrm{N} / \mathrm{A}$ \\
\hline Ohio & $\begin{array}{l}\text { Charter schools may use a school district facility under any contract terms that the district agrees to. Charter } \\
\text { schools may use loans obtained under the state facilities loan guarantee program for the construction of new } \\
\text { school buildings. If a board of education decides to dispose of property suitable for classroom space, it must } \\
\text { first offer the property for sale to start up community schools. }\end{array}$ \\
\hline Oklahoma & State has established an "incentive fund" for charter school renovation and remodeling of existing building. \\
\hline Oregon & $\begin{array}{l}\text { To the extent such information is readily available, education service districts must make lists of vacant } \\
\text { buildings available to the public; however, there is no preference or obligation to lease to a charter school. }\end{array}$ \\
\hline Pennsylvania & No facilities assistance provisions. \\
\hline Puerto Rico & No facilities assistance provisions. \\
\hline Rhode Island & $\begin{array}{l}\text { Public charter schools sponsored by school districts are eligible for reimbursement of "school housing costs." } \\
\text { Public charter schools not sponsored by school districts are eligible for } 30 \text { percent reimbursement of "school } \\
\text { housing costs." }\end{array}$ \\
\hline
\end{tabular}


Appendix II: Charter School Facility

Assistance Provisions, as of July 2003

\begin{tabular}{ll}
\hline \hline State & State requirements pertaining to facility assistance for charter schools. \\
\hline South Carolina & $\begin{array}{l}\text { State must publish an annual list of vacant state buildings. Charter schools have a "right of first refusal" for } \\
\text { vacant school buildings. }\end{array}$ \\
\hline South Dakota & N/A \\
\hline Tennessee & No facilities assistance provisions. \\
\hline Texas & Nonprofit revenue bonds may be issued for facilities assistance. \\
\hline Utah & No facilities assistance provisions. \\
\hline Vermont & N/A \\
\hline Virginia & Charter schools do not have to pay rent for available school buildings. \\
\hline Washington & N/A \\
\hline West Virginia & N/A \\
\hline Wisconsin & No facilities assistance provisions. \\
\hline Wyoming & Charter schools are not required to pay rent for school property “deemed available" in school district. \\
\hline Source: GAO analysis. &
\end{tabular}




\section{Appendix III: Charter Schools Operating during 2002-03 School Year in D.C. and Facility Status}

\begin{tabular}{|c|c|c|c|}
\hline & Charter schools campus & $\begin{array}{l}\text { Occupied a former DCPS } \\
\text { building at start-up }\end{array}$ & Current facility status \\
\hline \multicolumn{4}{|c|}{ Authorized by D.C. Public Charter School Board } \\
\hline 1 & Arts and Technology Academy & $\mathrm{Y}$ & $\begin{array}{l}\text { Purchased former DCPS } \\
\text { building }\end{array}$ \\
\hline 2 & Associates for Renewal in Education ${ }^{a}$ & $\mathrm{Y}$ & Leasing DCPS building \\
\hline 3 & Capital City & $\mathrm{N}$ & Leasing commercial space \\
\hline 4 & Carlos Rosario International & $\mathrm{Y}$ & $\begin{array}{l}\text { Leasing nonprofit and } \\
\text { commercial space, } \\
\text { purchased facility for use } \\
\text { beginning SY } 2003\end{array}$ \\
\hline 5 & $\begin{array}{l}\text { César Chávez Public Charter High } \\
\text { School for Public Policy }\end{array}$ & $\mathrm{N}$ & Leasing commercial space \\
\hline 6 & $\begin{array}{l}\text { Friendship-Edison Blow Pierce Junior } \\
\text { Academy Public Charter School }\end{array}$ & $\mathrm{Y}$ & $\begin{array}{l}\text { Purchased former DCPS } \\
\text { building }\end{array}$ \\
\hline 7 & $\begin{array}{l}\text { Friendship-Edison CG Woodson } \\
\text { Senior Academy Public Charter } \\
\text { School }\end{array}$ & $\mathrm{Y}$ & Leasing DCPS building \\
\hline 8 & $\begin{array}{l}\text { Friendship-Edison Chamberlain } \\
\text { Public Charter School }\end{array}$ & $\bar{Y}$ & $\begin{array}{l}\text { Purchased former DCPS } \\
\text { building }\end{array}$ \\
\hline 9 & $\begin{array}{l}\text { Friendship-Edison Woodridge Public } \\
\text { Charter School }\end{array}$ & $\mathrm{Y}$ & $\begin{array}{l}\text { Purchased former DCPS } \\
\text { building }\end{array}$ \\
\hline 10 & $\begin{array}{l}\text { Howard Road Academy Public } \\
\text { Charter School }\end{array}$ & $\mathrm{Y}$ & Owns new building \\
\hline 11 & $\begin{array}{l}\text { KIPP DC/KEY Academy Public } \\
\text { Charter School }\end{array}$ & $\mathrm{N}$ & Leasing commercial space \\
\hline 12 & $\begin{array}{l}\text { Marriott Hospitality Public Charter } \\
\text { High School }\end{array}$ & $\mathrm{N}$ & $\begin{array}{l}\text { Leasing former D.C. } \\
\text { government building }\end{array}$ \\
\hline 13 & $\begin{array}{l}\text { Maya Angelou See Forever Public } \\
\text { Charter School }\end{array}$ & $\mathrm{Y}$ & $\begin{array}{l}\text { Purchased commercial } \\
\text { building }\end{array}$ \\
\hline 14 & Meridian Public Charter School & $\mathrm{N}$ & Leasing commercial space \\
\hline 15 & $\begin{array}{l}\text { New School for Enterprise and } \\
\text { Development Public Charter School }\end{array}$ & $\mathrm{Y}$ & Leasing commercial space \\
\hline 16 & Paul JHS Public Charter School & $\mathrm{Y}$ & $\begin{array}{l}\text { Conversion school - leasing } \\
\text { from DCPS }\end{array}$ \\
\hline 17 & Sasha Bruce Public Charter School & $\mathrm{N}$ & $\begin{array}{l}\text { Will lease space from CSDC } \\
\text { in fall } 2003\end{array}$ \\
\hline 18 & $\begin{array}{l}\text { School for Arts in Learning Public } \\
\text { Charter School }\end{array}$ & $\mathrm{N}$ & Purchased private building \\
\hline 19 & SEED Public Charter School & $\mathrm{N}$ & Leasing DCPS building \\
\hline 20 & $\begin{array}{l}\text { South East Academy Public Charter } \\
\text { School }\end{array}$ & $\mathrm{N}$ & $\begin{array}{l}\text { Purchased commercial } \\
\text { building }\end{array}$ \\
\hline
\end{tabular}




\begin{tabular}{|c|c|c|c|}
\hline & Charter schools campus & $\begin{array}{l}\text { Occupied a former DCPS } \\
\text { building at start-up }\end{array}$ & Current facility status \\
\hline 21 & $\begin{array}{l}\text { Thurgood Marshall Academy Public } \\
\text { Charter School }\end{array}$ & $\mathrm{N}$ & $\begin{array}{l}\text { Leases from a nonprofit; sale } \\
\text { pending for DCPS building }\end{array}$ \\
\hline 22 & Tree of Life Public Charter School & $\mathrm{N}$ & Leases commercial space \\
\hline 23 & $\begin{array}{l}\text { Tri-Community Public Charter } \\
\text { Schoool }\end{array}$ & $\mathrm{N}$ & $\begin{array}{l}\text { Leasing from soldier's home } \\
\text { (federal government } \\
\text { property) beginning school } \\
\text { year } 2003\end{array}$ \\
\hline 24 & $\begin{array}{l}\text { Washington Math Science and } \\
\text { Technology Public Charter School }\end{array}$ & $\mathrm{N}$ & Leasing commercial space \\
\hline \multicolumn{4}{|c|}{ Authorized by the D.C. Board of Education } \\
\hline 25 & Barbara Jordan PCS & $\mathrm{Y}$ & $\begin{array}{l}\text { Leasing DCPS space in the } \\
\text { hub school }\end{array}$ \\
\hline 26 & Booker T. Washington PCS & $\mathrm{N}$ & Leasing commercial space \\
\hline 27 & Children's Studio PCS & $\mathrm{Y}$ & Leasing a DCPS building \\
\hline 28 & Community Academy PCS & $\mathrm{Y}$ & $\begin{array}{l}\text { Leasing DCPS building; } \\
\text { pending sale }\end{array}$ \\
\hline 29 & $\begin{array}{l}\text { Elsie Whitlow Stokes Community } \\
\text { Freedom PCS }\end{array}$ & $\mathrm{N}$ & Leasing from a nonprofit \\
\hline 30 & Hyde Leadership PCS & $\mathrm{Y}$ & Leasing DCPS building \\
\hline 31 & Ideal Academy PCS & $\mathrm{Y}$ & $\begin{array}{l}\text { Leasing DCPS space in the } \\
\text { hub school }\end{array}$ \\
\hline 32 & $\begin{array}{l}\text { Integrated Design Electronic } \\
\text { Academy (IDEA) PCS }\end{array}$ & $\mathrm{Y}$ & $\begin{array}{l}\text { Purchased former DCPS } \\
\text { building }\end{array}$ \\
\hline 33 & JOS-ARZ Therapeutic PCS & $\mathrm{N}$ & Leasing commercial space \\
\hline 34 & $\begin{array}{l}\text { Kamit Institute for Magnificent } \\
\text { Achievers (KIMA) PCS }\end{array}$ & $\mathrm{Y}$ & $\begin{array}{l}\text { Leasing DCPS space in the } \\
\text { hub school }\end{array}$ \\
\hline 35 & Next Step PCS & $\mathrm{N}$ & $\begin{array}{l}\text { Leasing commercial space } \\
\text { from Latin American Youth } \\
\text { Center }\end{array}$ \\
\hline 36 & Options PCS & $\mathrm{N}$ & $\begin{array}{l}\text { Leasing commercial space, } \\
\text { will move into CSDC space } \\
\text { fall } 2003\end{array}$ \\
\hline 37 & Roots PCS & $\mathrm{N}$ & Purchased the building \\
\hline 38 & $\begin{array}{l}\text { Village Learning Center PCS } \\
\text { (elementary school) }\end{array}$ & $\mathrm{N}$ & Leasing commercial space \\
\hline 39 & $\begin{array}{l}\text { Village Learning Center PCS (middle } \\
\text { and high school) }\end{array}$ & $\mathrm{Y}$ & Leasing DCPS building \\
\hline
\end{tabular}

Source: D.C. Public Charter School Board and DCPS Board of Education.

Note: Public Charter School (PCS).

${ }^{\text {a } A s s o c i a t e s ~ f o r ~ R e n e w a l ~ i n ~ E d u c a t i o n ~ P C S ~ c l o s e d ~ i n ~ J u n e ~} 2003$. 


\section{Appendix IV: A Comparison of Number of Charter Schools and Select Resources Available}

\begin{tabular}{|c|c|c|c|c|}
\hline State & $\begin{array}{r}\text { Number of charter } \\
\text { schools 2002-03 }^{\text {school year }}\end{array}$ & $\begin{array}{r}\text { Size of federal Public } \\
\text { Charter School State Grant } \\
\text { (\$ for FY 02) }\end{array}$ & $\begin{array}{l}\text { Law provides for } \\
\text { facilities funding }\end{array}$ & $\begin{array}{l}\text { Law allows access to } \\
\text { public facilities }\end{array}$ \\
\hline Alaska & 15 & 0 & No & Yes \\
\hline Arizona & 464 & $\$ 16,850,260$ & Yes & Yes \\
\hline Arkansas & 8 & $\$ 1,022,000$ & No & No \\
\hline California & 428 & $\$ 24,845,129$ & Yes & Yes \\
\hline Colorado & 93 & $\$ 7,141,048$ & Yes & Yes \\
\hline Connecticut & 16 & $\$ 200,000$ & Yes & No \\
\hline Delaware & 11 & $\$ 1,066,666$ & No & Yes \\
\hline District of Columbia & $35^{b}$ & $\$ 2,941,177$ & Yes & Yes \\
\hline Florida & 227 & $\$ 25,564,000$ & Yes & Yes \\
\hline Georgia & 35 & $\$ 100$ & No & No \\
\hline Hawaii & 25 & $\$ 4,368,421$ & No & No \\
\hline Idaho & 13 & $\$ 1,129,412$ & No & No \\
\hline Illinois & 29 & $\$ 1,136,446$ & No & Yes \\
\hline Indiana & 10 & $\$ 3,947,638$ & No & No \\
\hline lowa & 0 & 0 & No & No \\
\hline Kansas & 30 & $\$ 3,000,000$ & No & No \\
\hline Louisiana & 20 & $\$ 100$ & No & Yes \\
\hline Maryland & $0^{c}$ & 0 & No & No \\
\hline Massachusetts & 46 & $\$ 3,387,247$ & Yes & No \\
\hline Michigan & 196 & $\$ 6,081,376$ & No & No \\
\hline Minnesota & 87 & $\$ 9,970,543$ & Yes & Yes \\
\hline Mississippi & 1 & 0 & No & No \\
\hline Missouri & 26 & $\$ 100$ & No & No \\
\hline Nevada & 13 & $\$ 2,627,520$ & No & No \\
\hline New Hampshire & 0 & $\$ 10,000$ & No & Yes \\
\hline New Jersey & 56 & $\$ 3,552,828$ & No & No \\
\hline New Mexico & 28 & $\$ 5,125,000$ & Yes & Yes \\
\hline New York & 38 & $\$ 4,727,267$ & Yes & Yes \\
\hline North Carolina & 93 & $\$ 4,284,210$ & No & Yes \\
\hline Ohio & 131 & $\$ 21,044,050$ & No & Yes \\
\hline Oklahoma & 10 & $\$ 529,412$ & Yes & No \\
\hline Oregon & 25 & $\$ 5,293,582$ & No & Yes \\
\hline Pennsylvania & 91 & $\$ 8,507,000$ & No & No \\
\hline Puerto Rico & $1^{d}$ & 0 & No & No \\
\hline
\end{tabular}


Appendix IV: A Comparison of Number of

Charter Schools and Select Resources

Available

\begin{tabular}{|c|c|c|c|c|}
\hline State & $\begin{array}{r}\text { Number of charter } \\
\text { schools } 2002-03 \\
\text { school year }\end{array}$ & $\begin{array}{r}\text { Size of federal Public } \\
\text { Charter School State Grant } \\
\text { (\$ for FY 02) }\end{array}$ & $\begin{array}{l}\text { Law provides for } \\
\text { facilities funding }\end{array}$ & $\begin{array}{l}\text { Law allows access to } \\
\text { public facilities }\end{array}$ \\
\hline Rhode Island & 8 & $\$ 100$ & Yes & No \\
\hline South Carolina & 13 & $\$ 4,193,313$ & No & Yes \\
\hline Tennessee & 0 & $\$ 1,710,526$ & No & No \\
\hline Texas & 221 & $\$ 10,900,000$ & No & No \\
\hline Utah & 12 & $\$ 2,252,250$ & No & No \\
\hline Virginia & 8 & $\$ 525,694$ & No & Yes \\
\hline Wisconsin & 130 & $\$ 9,452,160$ & No & No \\
\hline Wyoming & 1 & $\$ 168,500$ & No & Yes \\
\hline
\end{tabular}

Source: GAO analysis.

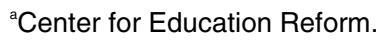

${ }^{\mathrm{b}} \mathrm{GAO}$ analysis - 35 charter schools operate on 39 campuses.

'Maryland did not pass its charter school law until May 2003.

${ }^{d}$ As of the 1999-2000 school year, according to Education. 


\section{Appendix V: GAO Contacts and Staff Acknowledgments}




\section{Related GAO Products}

Public Schools: Insufficient Research to Determine Effectiveness of Selected Private Education Companies. GAO-03-11. Washington, D.C.: October 29, 2002.

School Vouchers: Characteristics of Privately Funded Programs. GAO-02-752. Washington, D.C.: September 26, 2002.

School Vouchers: Publicly Funded Programs in Cleveland and Milwaukee. GAO-01-914. Washington, D.C.: August 31, 2001.

Charter Schools: Limited Access to Facility Financing. GAO/HEHS-00-163. Washington, D.C.: September 12, 2000.

Charter Schools: Federal Funding Available but Barriers Exist. GAO/HEHS-98-84. Washington, D.C.: April 30, 1998.

Charter Schools: Recent Experiences in Accessing Federal Funds. GAO/T-HEHS-98-129. Washington, D.C.: March 31, 1998.

Charter Schools: Issues Affecting Access to Federal Funds. GAO-T-HEHS-97-216. Washington, D.C.: September 16, 1997.

Private Management of Public Schools: Early Experiences in Four School Districts. GAO/HEHS-96-3. Washington, D.C.: April 19, 1996.

Charter Schools: New Model for Public Schools Provides Opportunities and Challenges. GAO/HEHS-95-42. Washington, D.C.: January 18, 1995. 


\section{GAO's Mission}

The General Accounting Office, the audit, evaluation and investigative arm of Congress, exists to support Congress in meeting its constitutional responsibilities and to help improve the performance and accountability of the federal government for the American people. GAO examines the use of public funds; evaluates federal programs and policies; and provides analyses, recommendations, and other assistance to help Congress make informed oversight, policy, and funding decisions. GAO's commitment to good government is reflected in its core values of accountability, integrity, and reliability.

\section{Obtaining Copies of GAO Reports and Testimony}

The fastest and easiest way to obtain copies of GAO documents at no cost is through the Internet. GAO's Web site (www.gao.gov) contains abstracts and fulltext files of current reports and testimony and an expanding archive of older products. The Web site features a search engine to help you locate documents using key words and phrases. You can print these documents in their entirety, including charts and other graphics.

Each day, GAO issues a list of newly released reports, testimony, and correspondence. GAO posts this list, known as "Today's Reports," on its Web site daily. The list contains links to the full-text document files. To have GAO e-mail this list to you every afternoon, go to www.gao.gov and select "Subscribe to e-mail alerts" under the "Order GAO Products" heading.

\section{Order by Mail or Phone}

The first copy of each printed report is free. Additional copies are $\$ 2$ each. A check or money order should be made out to the Superintendent of Documents. GAO also accepts VISA and Mastercard. Orders for 100 or more copies mailed to a single address are discounted 25 percent. Orders should be sent to:

\section{U.S. General Accounting Office \\ 441 G Street NW, Room LM \\ Washington, D.C. 20548}

$\begin{array}{lll}\text { To order by Phone: } & \text { Voice: } & \text { (202) } 512-6000 \\ & \text { TDD: } & (202) 512-2537 \\ & \text { Fax: } & \text { (202) } 512-6061\end{array}$

\section{To Report Fraud, Waste, and Abuse in Federal Programs} Contact:

Web site: www.gao.gov/fraudnet/fraudnet.htm E-mail: fraudnet@gao.gov Automated answering system: (800) 424-5454 or (202) 512-7470 